\title{
G Protein-Coupled Receptor Kinase 7
}

National Cancer Institute

\section{Source}

National Cancer Institute. G Protein-Coupled Receptor Kinase 7. NCI Thesaurus. Code C26242.

G protein-coupled receptor kinase 7 (553 aa, $62 \mathrm{kDa}$ ) is encoded by the human GRK7 gene. This protein plays a role in the phosphorylation of opsins which modulates the photoresponsiveness of cone cells. 